\title{
Karya-Karya Seni Tarannum dalam Bahasa Arab
}

\author{
Arabic Works on Tarannum
}

WAN HILMI WAN ABDULLAH*, HAMDI ISHAK \& SABRI MOHAMAD ${ }^{1}$

\begin{abstract}
This article describes the Arabic works on Tarannum art. The sources of traditional texts in this field of study are in deed very limited. Therefore, the objective of this study is to explore new books related to tarannum art. The design of this study is a library study using document analysis method. The findings show that there are twenty one works related to tarannum knowledge in Arabic published by various publishers. This study summarizes all the books as well as provides some highlights on the biography of reciters including life history, education, experience, recording and reading techniques.
\end{abstract}

Keywords: Qira'at, Quranic recitation, tarannum, tajwid, the Quran

Artikel ini membincangkan penulisan atau karya bidang tarannum dalam bahasa Arab. Setelah beberapa dekad yang lalu dan memasuki pada abad ke 21, terdapat lebih daripada 20 buah karya yang telah ditulis dan disusun merangkumi pelbagai tajuk perbahasan dan perbincangan. Laman web, http://ndjaawi.blogspot.my (2011) melaporkan bahawa karya penulisan yang pertama yang membincangkan perihal seni tilawah al-Quran adalah kitab Thakafah al-Quran yang dikarang oleh Abdul Wahhab Biwahdibah pada tahun 1760. Kitab tersebut menghuraikan tentang persoalan mengenai perasaan dan perbuatan dalam jiwa pada bacaan al-Quran. Namun begitu, perbincangan dalam penulisan tersebut adalah sangat terhad dan hanya tertumpu kepada sebahagian daripada disiplin ilmu seni tilawah al-Quran.

Pada tahun 1959 muncul penulisan tentang qurra' Mesir bertajuk Alhan al-Sama' yang dikarang oleh seorang qari terkenal Mesir, Mahmud al-Sa'dani. ia merupakan sebuah karya terbitan kali pertama yang mengisahkan tentang biografi, sejarah, sikap, prinsip serta kehebatan qurra' Mesir. Kitab tersebut ditulis semasa beliau berada di dalam penjara kerana tuduhan terlibat dengan pemberontakan. Setelah keluar dari penjara, kitab itu tiada lagi di pasaran disebabkan isu sekatan dari media cetak dan penyiaran daripada kerajaan Mesir yang tidak membenarkan sebarang buku diterbitkan daripada pihak pemberontak.

Pada tahun 1996, kitab yang sama ditulis kembali oleh Shaykh Mahmud Sa'dani yang memaparkan nama-nama qurra' yang masyhur seperti Shaykh Muhammad Rif'at, Shaykh Mustafa Isma'il, Shaykh Ali Sifi dan Shaykh Muhammad Sadiq al-Minshawi. Selepas itu, diterbitkan pula kitabkitab lain yang sehingga kini dianggarkan melebihi 20 buah kitab dalam bidang tarannum

\footnotetext{
${ }^{1}$ Wan Hilmi Wan Abdullah* (corresponding author), M.A., lecturer at Centre of Islamic Heritage Sustainability, Faculty of Islamic Studies, Universiti Kebangsaan Malaysia, 43600 BANGI, Selangor, Malaysia, emel: hjmiey@ukm.my; Hamdi Ishak, Ph.D., lecturer at Centre of Islamic Heritage Sustainability, Faculty of Islamic Studies, Universiti Kebangsaan Malaysia, 43600 BANGI, Selangor, Malaysia, emel: hamdi@ukm.edu.my; Sabri Mohamad, Ph.D., lecturer at Centre of Islamic Heritage Sustainability, Faculty of Islamic Studies, Universiti Kebangsaan Malaysia, 43600 BANGI, Selangor, Malaysia, emel: sabri_mohamad@ukm.my.
} 
merangkumi pelbagai perbahasan. Ia merupakan kitab-kitab dalam bahasa Arab yang ditemui kebanyakannya di perpustakaan negara Mesir.

Karya penulisan kitab berkaitan bidang seni tarannum telah mendapat perhatian dari pelbagai pihak. Ia bukan sahaja di kalangan para qari, tetapi juga dari pihak institusi kerajaan dan media cetak menerbitkan artikel dalam pelbagai bentuk seperti buku, berita, portal, segmen serta kupasan isu-isu dalam akhbar-akhbar utama. Didapati banyak laman web yang membuat pemerhatian dan kupasan terhadap pelbagai isu ataupun komentar tentang beberapa aspek seperti istilah-istilah, hukum bacaan, pengkaedahan tarannum, teknik-teknik suara, biografi sejarah tokoh qari dan lain-lain. Antara laman web yang terkenal adalah seperti www.qquran.com, www.mazameer.com, www.islamway.net, www.islamqa.info, al-Misr al-Yaum, Masress.com, Kotobwakotab.com, egypt.com, ahram.org.eg, elbadil.news, youm7.com, alyoumnew.com, dan massai.ahram.org.eg, alwafd.org. Stesen penyiaran juga telah menyiarkan pelbagai rancangan yang berkaitan al-Quran. Salah satu penyiar terkenal di Mesir ialah Iza'ah al-Quran al-Misriyyah yang ditubuhkan pada 25 Mei 1964 di era pemerintahan Presiden Mesir kedua, Raja Farouk (1920-1965). Penubuhannya adalah bertujuan memastikan al-Quran terus terpelihara dan berdiri teguh di bawah payung para huffaz dan qari (Wan Hilmi 2014).

Seorang ketua di Pejabat Pengurusan al-Tahrir, Kamal Najmi adalah merupakan seorang pegawai yang banyak memberi bantuan dan kerjasama penuh dalam menyusun beberapa buah kitab yang berkaitan dengan biografi sejarah tokoh qari Mesir. Kitab yang berjudul Abaqirah al-Tilawah fi Qarn al-Ish'rin adalah sebuah karya agung yang sangat besar nilai dan sumbangannya terhadap dunia tilawah al-Quran di Mesir. Kitab tersebut telah menyenaraikan seramai 168 qari tersohor di bumi kinanah. Beliau juga turut mengarang kitab tentang ketokohan Shaykh Mustafa Isma'il, seorang qari agung di zaman Shaykh Muhammad Rif'at dan Shaykh Mahmud Ali al-Banna. Kitab itu adalah keluaran dari Maktabah Dar al-Hilal, Kaherah yang diterbitkan pada tahun 1992.

Lidah rasmi al-Azhar iaitu Majalah Saut al-Azhar (2017) juga berperanan menyiarkan tulisan-tulisan berkenaan tokoh-tokoh qurra' dari Mesir seperti Shaykh Muhammad Rif'at, Shaykh Mustafa Isma'il, Shaykh Abd al-Basit, Shaykh Muhammad Sadiq al-Minshawi, Shaykh Mahmud Khalil al-Husari dan lain-lain. Terbitan pada keluaran bulan Julai 2017 menyebutkan mengenai kehebatan seorang qari terkenal iaitu Shaykh Muhammad Rif'at di mana beliau dianggap sebagai Hadiah alSama' ila al-Ardh (Hadiah dari Langit ke Bumi) yang bermaksud seorang qari yang lahir untuk tatapan penduduk dunia atas kelunakan dan kemerduan suaranya dalam alunan al-Quran. Majalah tersebut juga berkongsi artikel mengenai topik jama ' qira'at dalam kalangan golongan qurra' di majlis-majlis bacaan al-Quran.

Karya-karya penulisan yang berkaitan dengan bidang seni tarannum boleh diperolehi dari negara Timur Tengah seperti Mesir, Saudi, Syria, Iran dan lain-lain. Namun negara Mesir lebih terkehadapan dalam penerbitan buku-buku tersebut kerana mereka memiliki ramai qari dan sarjana yang terlibat secara langsung dalam bidang tarannum ini. Antara penulis yang terkenal dalam bidang tarannum di Mesir ialah Kamal Najmi, Nabil Hanafi, Mahmud Sa'dani, Syukri al-Qadhi, Ahmad alBuluk, Amal al-Banna, Muhammad al-Shafi'i, Rania Yahya, Muhammad Ridhwan, Muhammad Hasan, Abdul Rahman 'Iwadh, Muhammad Shalbi, Ashraf Abu al-Yazid, Ahmad Shamikh, Muhammad alKhawli, Mahmud al-Khawli, Muhammad Fathi Farj, Ramadhan Ramadhan Mutawalli, Mustafa Abu 'Ayid, Huda al-al-Kashif, Solah Zibadi, Yasmin Faraj, Abdul Tawwab Mustafa, Muhammad al-Sayyid, Sabri Abu 'Ilm, Husin Qadri, Muhammad Yusuf Ahmad dan Ahmad al-Bakri dan Ali Rizq (Muhammad al-Shafi/Ahmad al-Bakri 2014).

Penulis dari Semenanjung Tanah Arab pula seperti Solah Salim dan Muhammad Bantajuh serta dari Syria seperti Muhammad 'Arabi al-Qabbani. Contoh penulisan karya dalam bidang tarannum adalah seperti kitab Nujum al- 'Asr al-Zahabi li Dawlah al-Tilawah yang memuatkan senarai 
nama qurra' dari pelbagai latar belakang pengajian al-Quran seperti Shaykh Mahmud Khalil al-Husari yang terkenal dengan Alim al-Qira'at serta Shaykh Mustafa Isma'il pula digelar dengan Ahl al-Fann. Kitab tersebut menghimpunkan qari-qari sama ada membaca secara mujawwad mahupun murattal (Nabil Hanafi 2011). Manakala karya penulisan di Saudi pula adalah seperti kitab Mawsu'ah Sufara' al-Quran al-Mu'asirin yang dikarang oleh Solah Salim (2012) yang menyenaraikan kumpulan qari yang membaca secara tartil dan berlagu iaitu 40 orang qurra' yang terdiri daripada Shaykh Ibrahim al-Akhdhar, Shaykh Ahmad bin Abd al-Aziz al-Zayyat, Shaykh Su'ud al-Shurim, Shaykh Sa'ad bin Sa'id al-Ghamidi, Shaykh Abdullah Basbar, Shaykh Abd al-Basit, Shaykh Muhammad Rif'at, Shaykh Muhammad Sadil al-Minshawi, Shaykh Muhammad Jibril, Shaykh Ali Muhammad al-Dhoffa', Shaykh Mahmud Abd al-Hakam, Shaykh Abdulrahman al-Sudais, Shaykh dan Ahmad Ruzayqi.

Karya-karya penulisan tentang judul peraturan disiplin ilmu tarannum telah mula diperbincangkan oleh para akademik di seluruh dunia. Dalam kitab Abaqirah al-Tilawah fi al-Qarn al'Ishrin karangan Syukri al-Qadhi telah menghuraikan beberapa permasalahan yang berkaitan dengan kaedah Uslub al-Ada (Gaya Persembahan) terhadap beberapa qari seperti Shaykh Mustafa Isma'il, Shaykh Muhammad Rif at, Shaykh Abd al-Basit dan Shaykh Ali al-Banna. Kajian oleh Wan Hilmi (2014) telah melaporkan bahawa gaya persembahan bacaan tarannum oleh qurra' Mesir telah memberi kesan yang amat mendalam terhadap bacaan oleh para qari di seluruh dunia termasuk qari dari Malaysia.

Ilmu dan peraturan seni tarannum mula diperkenalkan secara formal di negara Mesir iaitu melalui pelajaran tajwid dan ilmu maqamat di Universiti al-Azhar pada tahun 970 Masihi pada zaman pemerintahan kerajaan Fatimiah (Wan Hilmi 2014). Hal ini ada disebutkan dalam majalah al-Azhar pada keluaran tahun 2000. Karya-karya penulisan tarannum banyak dihasilkan oleh pelbagai latar belakang pengkaji yang terdiri daripada kalangan para qari, ilmuwan, pengkaji dan peminat. Antara karya dalam bidang tarannum adalah:

1. Qitharah al-Sama' oleh Mahmud Tawfiq al-Khawli (2011), terbitan Maktabah al-Azhariyyah.

2. Mustafa Isma'il Hayatuh fi Zilli al-Quran oleh Kamal Najmi (1992), terbitan Dar al-Hilal.

3. Nujum al-Asr al-Zahbi li Dawlah al-Tilawah oleh Nabil Hanafi (2011), terbitan Dar Akhbar alYawm.

4. Alhan al-Sama' oleh Mahmud al-Sa'dani (1996), terbitan Dar Akhbar al-Yawm.

5. 'Abaqirah al-Tilawah fi al-Qarn al-Ishrin oleh Shukri al-Qadi (1997), terbitan Dar alJumhuriyyah.

6. al-Quran wa Mashahir al-Qurra' oleh Faruq Fahmi (1994), terbitan Kitab Jumhuriyyah Misriyyah.

7. Ashar Man Qaraa al-Quran fi al-'Asr al-Hadis oleh Ahmad al-Buluk (2011), terbitan Dar alMa'arif.

8. al-Quran bi Sawt Misr oleh Abu Talib Mahmud (2016), terbitan al-Hai'ah al-Misriyyah al'Ammah li al-Kitab.

9. Aswat Samawiyyah oleh Sa'id Ibrahim Hasan (2012), terbitan Dar al-'Ilm wa al-Iman.

10. Sawt Tuhibbu al-Mala'ikah oleh Amal al-Banna (2011), terbitan Dar al-'Ulum li al-Nashr wa al-Tawzi'.

11. Aswat min Nur oleh Mahmud al-Khawli (1992), terbitan Dar al-Shabab al-'Arabi.

12. Sawt min al-Sama' oleh Zakaria Hamimi (2009), terbitan Hibah al-Nil al-'Arabiyyah.

13. Jamal al-Tilawah fi al-Sawt wa al-Nagham oleh al-Sayid Muhammad Rida (2012), terbitan Jam'iyyah al-Quran al-Karim li al-Tawjih wa al-Irshad.

14. al-Mukhtar oleh Abd al-Aziz al-Bashari (1935), terbitan al-Matba'ah Lujnah al-Ta'lif wa alNashr. 
15. Sufara al-Quran oleh Ahmad Hamam (1996). T.tt.

16. Fann Tarbiah al-Aswat oleh 'Atiyyah 'Abd al-Khaliq (1984), terbitan Maktabah al-Anjalu alMisriyyah.

17. Jami' al-Nafahat al-Qudsiyyah oleh Muhammad 'Arabi al-Qabbani (1998), terbitan Dar alKhayr.

18. Rihlati fi al-Islam oleh Mahmud Khalil al-Husari (t.t), terbitan Majma' al-Buhus al-Islamiyyah.

19. Dawlah al-Tilawah, Aswat min al-Sama' oleh Muhammad al-Shafi/Ahmad al-Bakri (2014), terbitan Dar al-Hilal.

20. Usul Fann Tilawah al-Quran al-Karim oleh Muhammad Bantajah (2015), terbitan Dar al-Kutub al-'Ilmiyyah.

21. Mawsu'ah Sufara' al-Quran al-Karim oleh Solah Salim (2012). Terbitan Dar Al-Hadharah li alNashr wa al-Tawzi'.

\section{Tokoh-tokoh Qurra' dalam Penulisan Karya Tarannum}

Dalam tulisan ini, penulis akan membincangkan tujuh orang tokoh qurra' yang bergiat aktif dalam memberikan sumbangan idea mereka dalam bidang tananum.

Shaykh Ahmad Nada (1868-1932)

Beliau ialah Ahmad Ahmad Abdul Salam, terkenal dengan panggilan Shaykh Ahmad Nada dilahirkan di Kaherah pada tahun 1868M. Syakh Ahmad bertugas sebagai muazzin di Masjid al-Sayyidah Zainab dan merupakan seorang qari terkenal yang dianggap sebagai qari sezaman dengan tiga qurra' terkenal angkatan pertama iaitu Shaykh Mahmud al-Qaysuni, Shaykh Husin al-Sawwaf dan Shaykh Hanafi Bar'ie. Shaykh Ahmad Nada bukan semata-mata berpengetahuan dalam muzik tetapi ahli dalam bidang ini (Nabil Hanafi 2011).

Shaykh Ahmad Nada mendapat pendidikan awal di bawah kelolaan pendidikan al-Azhari selepas tamat hafalan al-Quran. Kemudian melibatkan diri dengan pembacaan al-Quran di beberapa haflah dan munasabat di sekitar Kaherah (Abdul Aziz al-Bashari 1935). Beliau meninggal dunia pada hari Khamis, 21 Julai tahun 1932M bersamaan 17 Rabiul Awal 1351H.

Shaykh Muhammad Rif at (1880-1950)

Muhammad Rif'at dilahirkan pada tahun 1880M (Mahmud Tawfiq 2011) dan ada juga dikatakan pada hari Isnin 9 Mei 1882M (Shukri al-Qadi 1997). Shaykh Muhammad Rif'at merupakan qari rasmi di masjid Fadil Basha yang dilantik oleh pemerintah. Beliau telah meninggal dunia pada hari Isnin 9 Mei 1950. Selepas dua tahun daripada kelahiran, beliau ditimpa dengan penyakit pendarahan dalam kepala yang menyebabkan kedua-dua belah matanya menjadi buta. Walaupun begitu tidak sedikitpun mematahkan semangat dan keazaman beliau untuk terus menimba ilmu pengetahuan (Wan Hilmi 2014). Beliau qari pertama yang membaca dalam majlis perasmian siaran Idha'ah alMisriyyah pada tahun 1934 (Mahmud Tawfiq 2011). Shaykh Muhammad Rif at mendalami dan mempelajari ilmu tafsir, al-qira'at dan tajwid melalui gurunya Shaykh Muhammad al-Baghdadi dan Shaykh al-Samaluthi. Kemudian beliau belajar ilmu Usul al-Musiqi dengan menghafal beratus-ratus tausyih dan qasidah keagamaan. Shaykh Muhammad Rif'at telah berjaya menyempurnakan hafalan al-Quran sebelum berusia 10 tahun (Ahmad al-Buluk 1996). Diriwayatkan juga bahawa beliau telah mempelajari dan menyempurnakan ilmu al-Qira'at Saba'ah dengan Shaykh 'Abd al-Fattah Hunaydi (Faruq Fahmi 1994). 
Shaykh Muhammad Rif'at juga mempelajari ilmu Usul al-Musiqi dan kaedah-kaedahnya dengan pakar-pakar lagu sezaman dengannya dan menghafaz berpuluh-puluh bait lagu dan tausyihtausyih serta mempelajari alat permainan gabus (Faruq Fahmi 1994). Beliau telah diundang secara rasmi ke beberapa buah negara Arab dan Islam yang lain bagi menyertai dan menghidupkan program-program haflah-haflah dan majlis-majlis keagamaan (Shukri al-Qadhi 1997).

Shaykh Mustafa Isma'il (1905-1978)

Mustafa Muhammad Mursi Ibrahim Isma'il dilahirkan pada 17 Jun 1905 di sebuah desa yang terkenal dengan Mayt Ghazal Markaz al-Santah, Muhafazah Gharbiyyah, Tonto kira-kira 300 kilometer dari Bandar Kaherah, Mesir (Kamal Najmi 1992). Shaykh Mustafa Isma'il merupakan anak sulung daripada lapan orang adik-beradik. Tiga daripadanya adalah lelaki iaitu 'Abd al-Salam, Muhammad dan 'Abd al-Aziz, manakala saudara perempuan perempuannya Zakiah, Aminah, Fatimah, Sittul 'A'ilah dan Sariah (Kamal Najmi 1992).

Shaykh Mustafa Isma'il memiliki enam cahaya mata iaitu 'Atif Mustafa Isma'il (anak sulung), tinggal di Jerman semenjak 1953 dan kini berkerja sebagai usahawan, Mahmud Samir (Pegawai di Syarikat Kapal Terbang Misr Tayran), Ahmad Wahid (Pengerusi di bahagian Perkhidmatan dan Kawalan Televisyen Mesir), manakala anak-anak perempuan pula ialah Anji, Samiyah dan Majidah (Kamal Najmi 1992). Bapa Shaykh Mustafa Isma'il ialah Muhammad al-Mursi Isma'il adalah seorang petani dan ibunya Sititah Husnayn Ismaill. Datuknya sebelah bapanya dipanggil al-Mursi Ibrahim Isma'il, manakala datuk sebelah ibu dipanggil al-Sayyid Isma'il. Neneknya diberi nama Asmah alSayid Isma'il (Kamal Najmi 1992).

Beliau mendapat pendidikan awal pada seusia 6 tahun, kemudian dihantar ke sebuah kuttab yang terletak di kampung halamannya yang dipimpin oleh Shaykh 'Abd al-Rahman 'Abu al-'Aynin. Beliau hanya sempat belajar selama 2 tahun dengan mempelajari kaedah cara membaca, menulis dan menghafaz $1 / 4$ dari juzuk al-Quran di kuttab tersebut. Setelah itu, beliau menyambung pelajarannya ke kuttab Shaykh Abdullah Syahatah yang terletak berhampiran dengan kediamannya di mana beliau menamatkan hafalan keseluruhan al-Quran serta menulis ayat al-Quran (Kamal Najmi 1992).

Menurut Shukri al-Qadi (1997), bakat dan potensi yang dimiliki Shaykh Mustafa Isma'il telah mendorong bapanya untuk menghantarnya menuntut bersama dua orang shaykh yang terkenal dan sangat dihormati yang tidak jauh dari kampungnya iaitu Shaykh Muhammad 'Abu Hashish dan Shaykh Idris Fakhir. Beliau belajar ilmu tajwid, ilmu qiraat dan mengulangi hafalan al-Quran. Shaykh Mustafa Isma'il juga berjaya menyempurnakan hafalan dengan Shaykh Abu Hashish ketika berusia 10 tahun. Shaykh Idris Fakhir merupakan guru yang sepenuhnya menggalas tanggungjawab untuk menyemak bacaan Shaykh Mustafa Isma'il. Beliau mempelajari ilmu tajwid dan qira'at dengan Shaykh Idris Fakhir ketika usianya mencapai 16 tahun sebelum meneruskan pengajian ke Maahad Diniah Tonto. Beliau telah menamatkan ulangan hafalan bersama gurunya Shaykh Idris Fakhir sebanyak 30 kali khatam. Shaykh Mustafa Isma'il meninggal dunia pada 23 Disember 1978 sekembali beliau dari majlis perasmian Jami al-Bahr pada tanggal 22 Disember 1978 setelah beliau ditimpa dengan pendarahan dalam kepala dan koma selama satu hari (Kamal Najmi 1992).

Shaykh `Abd al-Basit (1927-1988)

'Abd al-Basit Muhammad 'Abd al-Samad dilahirkan pada tahun 1927M di kampung al-Mara'izah yang terletak di Markaz Armant, al-Daffah al-Gharbiyyah, berdekatan sungai Nil. Markaz Armant tersebut terletak kira-kira 20 kilometer dari selatan bandar al-Aqsar al-Shahirah atau 691 kilometer dari 
bandar Kaherah (Zakaria Hamimi 2009). Shaykh 'Abd al-Basit merupakan anak ketiga daripada empat orang adik-beradik iaitu Mahmud (anak sulung), 'Abd al-Hamid, 'Abd al-Basit dan 'Abd alMun'im (anak bongsu) (Shukri al-Qadi 1997).

Shaykh 'Abd al-Basit mendapat pendidikan awal pada tahun 1934 di kuttab Shaykh al-Amir, kampung Armant al-Waburat. Beliau menamatkan hafalan al-Quran keseluruhannya bersama Shaykh al-Amir pada usia 10 tahun pada tahun 1937M (Zakaria Hamimi 2009). Beliau seterusnya menyambung pengajian bersama Shaykh Muhammad bin Salim Hamadah, seorang guru al-Quran dan al-Qira'at yang berasal dari Markaz al-Minsyah, Muhafazah Suhaj. Sepanjang tiga tahun berguru dengan Shaykh Muhammad Salim Hamadah al-Minshawi, iaitu murid kepada seorang yang alim qiraat terkenal di al-Azhar Shaykh, Muhammad Su'udi Ibrahim, maka pada tahun 1940 dalam usia 13 tahun Shaykh 'Abd al-Basit telah berjaya memperolehi ijazah al-Qira'at al-Saba'. Selain itu beliau turut memberi perhatian kepada ilmu syariah dan bahasa Arab, di samping menghafaz Matan Shatibiyyah dan beberapa kitab yang lain seperti kitab al-'Iqd al-Farid (Zakaria Hamimi 2009).

Shaykh 'Abd al-Basit pernah berkunjung lebih daripada 100 kali ke luar negara. Beliau telah berjaya mengislamkan seramai 92 orang di negara Uganda dan 30 orang di Amerika Syarikat semasa lawatan pertama kalinya ke sana kira-kira pada tahun 70 an (Zakaria Hamimi 2009). Shaykh 'Abd alBasit telah dianugerahkan dengan pelbagai pingat kebesaran sepanjang penglibatan beliau dalam bidang tilawah al-Quran. Beliau meninggal dunia pada 30 November 1988 (Shukri al-Qadi 1997).

$$
\text { Shaykh Mahmud Khalil al-Husari (1917-1980) }
$$

Mahmud Khalil al-Husari dilahirkan di Qaryah Shubra al-Namlah pada 27 September 1917M (Nabil Hanafi 2011). Beliau mendapat pendidikan awal seusia 5 tahun di kuttab yang berada dikampungnya. Setelah meningkat dewasa dan dibekalkan dengan hafalan al-Quran serta ilmu-ilmu agama yang cukup, beliau dihantar pula ke Masjid Sayyidi Ahmad al-Badawi, Tonto. Di sana terdapat perpustakaan yang menghimpunkan khazanah besar turath dan sumber-sumber ilmu qiraat. Beliau telah berjaya menamatkan hafalan al-Quran di masjid tersebut, kemudian menyambung pengajian dalam bidang qiraat sehingga tamat bacaan qiraat sepuluh (Nabil Hanafi 2011). Dengan anugerah suara yang sedap dan menarik, beliau memulakan penglibatan membaca al-Quran kepada masyarakat di sekitar daerah Shubra al-Namlah dan Tonto. Setelah mencapai usia matang sekitar umur 20 an, suara beliau mula bergema di setiap pelosok Kaherah sekitar tahun 40 an (Nabil Hanafi 2011).

Shaykh Mahmud Khalil al-Husari dilantik sebagai qari rasmi di Iza'ah al-Quran oleh Lujnah Ikhtibar al-Qurra' al-Judad bi al-Iza'ah. Bersama beliau, dua orang lagi qari yang turut dilantik iaitu Shaykh Ahmad Abu al-Mu'ati dan Shaykh Muhammad Darbalah. Rakaman pertama beliau di Iza'ah pada 27 September 1944 mengambil masa selama 5 minit (Nabil Hanafi 2011). Shaykh Mahmud Khalil al-Husari merupakan qari al-Surah di Masjid Sayyidina al-Husain, menggantikan Shaykh Muhammad al-Siffi setelah beliau meninggal dunia.

Beliau dilantik dengan pelbagai tugas setelah berhijrah ke Kaherah. Antara tugasnya ialah sebagai Panel Penilai bagi Maqari' al-Misriyyah pada tahun 1957, Wakil Rasmi al-Maqari' alMisriyyah tahun 1958, Panel Penyemak dan Penilai Mushaf tahun 1959, Shaykh Umum al-Maqari alMisriyyah tahun 1960 dan Penasihat Institusi al-Quran di Kementerian Wakaf tahun 1961 (Ahmad al-Buluk 2011). Beliau banyak mengarang kitab berkaitan al-Quran seperti al-Sabil al-Muyassar fi Qira'at Imam Ja'far, Ahkam Qiraah al-Quran, al-Qira'at al-'Ashar, Ma'alim al-Ihtida' ila Ma'rifah alWaqf wa al-Ibtida' dan lain-lain (Nabil Hanafi 2011). Shaykh Mahmud Khalil bermusafir ke pelbagai negara, antaranya Paris, London, Perancis, Amerika, Lubnan, Syria, Palestin, Saudi, Malaysia, 
Indonesia, Nigeria, Pakistan lain-lain. Beliau meninggal dunia pada hari Isnin 24 November 1980 selepas menunaikan solat 'Isya (Mahmud Khalil T.t).

Shaykh Mahmud Ali al-Banna (1926-1985)

Beliau ialah Mahmud Ali al-Banna yang dilahirkan pada hari Jumaat 17 Disember 1926M di Syubra Bas, wilayah Manufiah, salah satu perkampungan di Syibin al-Kom. Mahmud telah dihantar ke kuttab Shaykh Musa berdekatan kampungnya untuk menghafaz al-Quran sehingga berjaya menamatkan hafalan sekitar usia 12 tahun.

Oleh kerana usia beliau masih muda, beliau tidak diterima masuk ke Maahad Agama Syibin al-Kom yang terletak tidak jauh dari kampung halamannya, maka beliau dihantar ke Maahad Agama al-Minshawi di wilayah Tonto bagi meneruskan pengajian. Semasa di kuttab Shaykh Musa, beliau mempelajari ilmu tajwid dan menghafaz al-Quran, namun ketika berada di Maahad Agama alMinshawi beliau mendalami pengajian dalam aspek kaedah cara tilawah, mengikuti kaedah tarannum Kibar al-Qurra' yang terkenal seperti Shaykh Muhammad Rif at dan Shaykh Muhammad al-Su'udi, qari di Masjid al-Ahmadi, Tonto (Nabil Hanafi 2011). Beliau juga meniru cara bacaan Shaykh Toha al-Fashni serta menghafaz tausyih dan zikir.

Shaykh Mahmud Ali al-Banna menuntut ilmu di Maahad Agama al-Minshawi selama 3 tahun dan berjaya menamatkan pengajian dalam bidang yang berkaitan dengan ilmu al-Quran. Kemudian beliau meneruskan langkah pencarian ilmu dengan mendaftar sebagai pelajar di Masjid Sayyidi Ahmad al-Badawi, Tonto. Di sini, beliau menyambung talaqqi al-Quran dengan mendalami lagi ilmu qiraat dan tajwid, di samping memperkasakan anugerah suara yang sedap bagi memantapkan lagi kemahiran dan penguasaan tilawah (Nabil Hanafi 2011). Beliau mula memasuki siaran Iza'ah pada tahun 1948 sempena majlis sambutan awal tahun baru hijrah yang berlangsung di lokasi Opera yang terletak di Kaherah (Nabil Hanafi 2011). Kemunculan Shaykh Mahmud Ali al-Banna dalam dunia tilawah seangkatan dengan qurra' besar yang lain seperti Shaykh Mustafa Isma'il, Abd al-Fattah alSha'sha'ie, Mansur al-Shami al-Damanhuri, Muhammad Rif'at, Abu al-'Ainin Sha'isha' dan Abd al'Azim Zahir. Beliau adalah qari pertama yang membaca al-Quran sempena majlis upacara memperingati kewafatan Raja Fu'ad pertama yang dibawa secara langsung dalam televisyen Mesir pada 22 April 1949. Beliau juga merupakan qari al-Surah di beberapa buah masjid besar, antaranya masjid al-Ahmadi di Tonto, masjid al-Malik, masjid al-Rifa'ie dan masjid al-Husain di Kaherah. Pelbagai negara telah dikunjungi bagi tujuan menyebarkan dakwah al-Quran (Nabil Hanafi 2011).

Shaykh Mahmud Ali al-Banna telah meninggalkan khazanah peninggalan yang sangat besar dalam tilawah al-Quran iaitu rakaman bacaan secara berlagu dan bacaan secara tartil. Beliau juga telah dianugerahkan dengan pelbagai pingat kebesaran dari pelbagai negara (Nabil Hanafi 2011). Di antara kejayaan Shakyh Mahmud Ali al-Banna ialah menubuhkan Kompleks Islam yang menempatkan sebuah masjid, bangunan tahfiz dan perpustakaan. Beliau meninggal dunia pada hari Sabtu, 20 Julai 1985.

\section{Shaykh Muhammad Sadiq al-Minshawi (1920-1969)}

Beliau ialah Muhammad Sadiq al-Minshawi, dilahirkan pada 20 Januari 1920 di al-Minsyah, muhafazah Suhaj sekarang. Bapa beliau Shaykh Sadiq al-Minshawi merupakan qari terkenal yang seangkatan dengan qari-qari besar yang lain seperti Shaykh Ahmad Nada, Mansur Badar, Ali Mahmud, Muhammad Rif'at dan Abd al-Fattah al-Sha'sha'ie (Ahmad al-Buluk 2011). Beliau mula menghafaz al-Quran ketika di usia kanak-kanak dan menamatkan hafalan pada umur 11 tahun di tangan gurunya, Shaykh Muhammad al-Namki (Nabil Hanafi 2011). 
Melihat kepada kekurangan dalam disiplin ilmu Ulum al-Quran, beliau seterusnya belajar ilmu tajwid dan ilmu qira'at bersama dua orang guru hebat iaitu Shaykh Muhammad Abu al-'Ala dan Shaykh Muhammad Su'udi (Ahmad al-Buluk 2011). Beliau juga mengambil ilmu al-Inshad (qasidah nasyid) daripada bapanya sendiri, Shaykh Sadiq yang merupakan ahli nasyid qasidah yang tersohor (Nabil Hanafi 2011). Shaykh Muhammad Sadiq al-Minshawi banyak memberi sumbangan kepada masyarakat setempat dengan memberi khidmat membaca al-Quran dan juga berqasidah (Nabil Hanafi 2011). Beliau juga merupakan salah seorang daripada 120 qari yang dipilih oleh Lujnah Penapisan yang dianggotai oleh pelbagai agensi, jabatan dan institusi sebagai qari bagi Pusat Iza'ah (Pusat Penyiaran Rasmi). Termasuk qurra' yang lain seperti Shaykh Mahmud Khalil al-Husari, Mahmud Ali al-Banna, Mansur Shami al-Damanhuri, Abd al-Rahman al-Duri, Mahmud Abd al-Hakam, Mustafa Isma'il, Abd al-Basit, Taha al-Fashni dan lain-lain. Antara panel pula terdiri daripada Shaykh Mahmud Syaltut, Shaykh Abd al-Fattah al-Qadhi dan Shaykh Muhammad al-Thabba'. Keistimewaan yang ada pada qurra' yang terpilih adalah berupaya menepati dengan hukum tajwid dan usul riwayat, serta memiliki suara yang lunak dan menarik (Nabil Hanafi 2011).

Tilawah pertama oleh Shaykh Muhammad Sadiq al-Minshawi di siaran al-Iza'ah pada 13 Jun 1954 dengan bacaan dari surah-surah pendek. Kemudian tilawah berikutnya yang kedua pada 30 Jun 1954, waktu petang hari Sabtu. Semenjak penampilan ini, suara beliau mula kedengaran di Iza'ah yang bersiaran pada setiap hari Rabu. Menurut Nabil Hanafi (2011), kelebihan suara yang dimiliki oleh Shaykh Muhammad Sadiq al-Minshawi ialah mempunyai unsur-unsur kekuatan, kelunakan dan penghayatan. Beliau juga mahir dalam disiplin ilmu tarannum seperti tabaqah suara iaitu qararat dan jawabat, selain mengetahui teknik nada menaik dan menurun mengikut penyesuaian makna ayat. Inilah menjadikan beliau sangat unik dan diminati ramai pendengar serta suara beliau sampai kepada pelosok dunia. Sumbangan besarnya ialah dalam turath rakaman berlagu (mujawwad) dan tartil (murattal). Beliau turut dianugerahkan pingat kebesaran dari pelbagai negara (Nabil Hanafi 2011). Perjalanan dakwah al-Qurannya merentasi dunia Islam yang lain seperti Syria, Malaysia dan Indonesia (Shukri al-Qadhi 1997). Shaykh Muhammad Sadiq al-Mishawi meninggal dunia pada malam Sabtu 21 Jun 1969 di usia masih muda iaitu 49 tahun.

\section{Karya-karya Seni Tarannum}

Dalam bahagian berikut penulis akan membincangkan secara ringkas karya-karya yang popular dalam bidang taranum, anataranya kitab Qitharah al-Sama', Mustafa Isma'il Hayatuh fi Zilli al-Quran Nujum al-'Asr al-Zahbi li Dawlah al-Tilawah, al-Quran bi Saut Misr, Aswat Samawiyyah, Dawlah alTilawah, Aswat min al-Sama', Saut Tuhibbu al-Mala'ikah dan Dawlah al-Tilawah, Aswat min al-Sama'

\section{Qitharah al-Sama' oleh Mahmud Tawfiq al-Khawli (2011)}

Kitab ini disusun oleh Mahmud Tawfiq al-Khawli dan diterbitkan oleh al-Maktabah al-Azhariyyah pada tahun 2011. Ia mengisahkan tentang kehidupan Shaykh Muhammad Rif'at bermula daripada kelahiran, perkembangan dan kewafatan beliau. Kehidupan Shayk Muhammad Rif'at dipenuhi dengan kemaafan, keimanan dan ketakwaan kepada Allah serta kitabnya, sekalipun beliau seorang yang miskin. Beliau mempelajari banyak disiplin ilmu pengetahuan seperti ulum tafsir, qiraat, tajwid, ilmu seni suara, ilmu muzik dan seni persembahan bagi melengkapkan diri sebagai seorang qari yang bersikap warak, alim dan tawaduk (Nabil Hanafi 2011). Kitab ini dapat mengenali beliau secara dekat sekalipun beliau tidak memasuki mana-mana universiti, namun kepintaran dan kebijaksanaan serta ikhlas dalam dengan kitab Allah menjadikannya dalam keberkatan dan kemuliaan Allah. 
Mustafa Isma'il Hayatuh fi Zilli al-Quran oleh Kamal Najmi (1992)

Kitab ini disusun oleh Kamal Najmi pada tahun 1992 dan diterbitkan di Dar al-Hilal, Kaherah. Ia merupakan sebuah kitab istimewa yang mengisahkan tentang sosok tubuh qari agung, Shaykh Mustafa Isma'il sepanjang penglibatan beliau dalam seni tilawah. Antara topik penting dalam kitab ini mengetengahkan biografi lengkap tentang Shaykh Mustafa, sejarah pengajiannya di zaman kanakkanak sehinggalah memasuki Maahad Diniah Tonto (Nabil Hanafi 2011). Selain itu, ia menyentuh tentang hubungan Shaykh Mustafa Isma'il dengan masyarakat dalam dan luar negeri terutama dalam aspek menyemai sikap mencintai al-Quran serta dakwah kepada golongan non Muslim di luar kawasan negara bukan Islam seperti Britain, Amerika, Perancis di mana beliau sering di undang ke sana bagi tujuan membaca al-Quran.

Sumbangan besar Shaykh Mustafa Isma'il terhadap turath al-Quran ialah rakaman al-Quran berbentuk mujawwad dan murattal yang lengkap keseluruhan juzuk al-Quran. Kini, peninggalan turath tersebut menjadi rujukan dan sumber utama kepada pencinta al-Quran khususnya seni tarannum.

Nujum al-'Asr al-Zahbi li Daulah al-Tilawah oleh Nabil Hanafi (2011)

Kitab ini disusun oleh Nabil Hanafi yang memuatkan biografi 15 bintang tersohor di dunia tilawah. Bintang di sini bermaksud orang yang lahir, muncul, tersebar, terkenal dan penuh keistimewaan serta sangat dikenali dalam dunia pengtilawahan. Kitab ini menukilkan tentang biografi qurra', sejarah keterlibatan dalam Iza'ah Misriyyah dan kaedah ilmu seni tilawah atau seni tarannum secara umum. Selain itu, ia mengisahkan juga tentang perkembangan dunia tilawah di Mesir, sejarah permulaan ilmu seni bacaan di zaman kerajaan Fatimiyyah serta sumbangan besar para qurra' dalam rakaman al-Quran sama ada secara murattal mahupun mujawwad.

\section{al-Quran bi Saut Misr oleh Abu Talib Mahmud (2016)}

Kitab ini dikarang oleh Abu Talib Mahmud yang diterbitkan oleh al-Hayah al-Misriyyah pada tahun 2016. Ia mengandungi 456 halaman bercetak dan merupakan sebuah karya yang sangat tebal. Kitab ini memuatkan sejarah latar belakang qurra' terkenal Mesir dan kesan kemunculan mereka terhadap seni tilawah al-Quran. Peranan yang dimainkan oleh Katatib (madrasah/pondok) menyumbang kepada kekuatan tilawah mereka dan mencorakkan personaliti akhlak mereka dalam bidang alQuran.

Kitab ini juga menyentuh tentang pengajian mereka terutama ilmu bacaan dan ilmu-ilmu yang lain, di samping penglibatan dalam rihlah quran serta kesan terhadap dunia Islam di mana mereka diberi anugerah yang tidak ternilai di sisi Allah s.w.t dengan kemuliaan, berakah, penghormatan dan cahaya kerana mencintai al-Quran. Kitab ini juga memfokuskan kepada matlamat mengangkat golongan qurra' sehingga mereka menjadi 'model' bagi generasi yang terdahulu dan akan datang mengikuti jalan mereka.

Aswat Samawiyyah oleh Sa'id Ibrahim Hasan (2012)

Kitab ini ditulis oleh Sa'id Ibrahim Hasan yang diterbitkan oleh Dar al-Ilm wa al-Iman pada tahun 2012. Kitab ini memuatkan senarai nama 131 orang qurra' yang terdiri daripada tokoh-tokoh hebat zaman ini. Kitab ini juga mengungkap biografi latar belakang tokoh, pengajian dan seni tarannum sepanjang penglibatan mereka dalam dunia tilawah al-Quran. 
Kitab ini menceritakan tentang perjalanan seorang lelaki, Shaykh Mahmud Ali al-Banna yang sangat mencintai al-Quran dan hidup dalam cahaya al-Quran serta taman-taman tilawah. Allah s.w.t membuka hatinya dengan mencintai al-Quran setelah jiwa dan hidupnya dibentuk dan dilakar melalui al-Quran. Ramai kalangan orang bercerita tentang beliau kerana keunikan suara beliau yang menghimpunkan antara kelunakan dan kesempurnaan, dan beliau digambarkan oleh pena-pena yang menulis sebagai seorang shaykh yang 'sangat unik'. Seorang yang memiliki perwatakan yang menarik dan memiliki suara yang sedap, juga dianggap sebagai duta al-Quran dan ikon tilawah. Memiliki akhlak yang terpuji adalah pemangkin kepada kejayaan dan menempa kemasyhuran yang luar biasa dalam dunia tilawah. Kitab ini membuka rahsia sebenar personaliti Shaykh Mahmud Ali al-Banna, kisah hidup beliau bersama para qurra' yang lain serta dakwah beliau melalui jalan alQuran yang telah disuluhi dengan cahaya terang benderang. Beliau layak digelar sebagai qari terbilang di zaman kegemilangan dunia tilawah pada abad 21.

Dawlah al-Tilawah, Aswat min al-Sama' oleh Muhammad al-Shafi/Ahmad al-Bakri (2014)

Kitab ini disusun oleh Ahmad al-Bakri, ketua pejabat al-Tahrir yang diselenggarakan oleh maktabah Dar al-Hilal. Kitab ini mengetengahkan 16 tokoh qari tersohor dari negara Mesir iaitu Shaykh Muhammad Rif'at, Shaykh Mustafa Isma'il, Shaykh Muhammad Sadiq al-Minshawi, Shaykh Abd alBasit, Shaykh Abd al-Fattah al-Sha'sha'ie, Shaykh Ali Mahmud, Shaykh Mahmud Ali al-Banna, Shaykh Mahmud Khalil al-Husari, Shaykh Taha al-Fashni, Shaykh Kamil Yusuf al-Bahtimi, Shaykh Abd al'Azim Zahir, Shaykh Sayyid al-Naqshabandi, Shaykh Nasruddin al-Tubbar, Shaykh Muhammad 'Imran dan Shaykh Ahmad al-Tuni. Kitab ini mengetengahkan juga tokoh-tokoh qurra' Haramain seperti Shaykh Ahmad bin Ali al-'Ajami, Shaykh Su'ud Ibrahim, Shaykh Abu Bakar al-Shatiri, Shaykh Tawfiq bin Sa'id al-Saigh, Shaykh Sa'id al-Ghamidi, Shaykh Solah al-Badir, Shaykh Muhammad bin Sulaiman al-Muhaysini, Shaykh Abd al-Rahman al-Sudays, Shaykh Ali Abdullah Jabir dan Shaykh Muhammad Abdullah al-Sabil.

Kitab yang dimulai dengan kalam sekapur sirih oleh Pengerusi al-Tahrir, Muhammad al-Shafi telah menjudulkan penulisan dengan lakaran Dawlah al-Tilawah di Mesir yang menggambarkan suara-suara qurra'sebagai perumpamaan suara-suara dari langit. Beliau berbicara tentang Madrasah al-Tilawah di Mesir yang berperanan besar dalam melahirkan qurra' yang hebat di dunia Islam. Para qurra' terkenal seperti Shaykh Mustafa Isma'il, Shaykh Muhammad Rif at, Shaykh Mahmud Khalil alHusari dan lain-lain memberi kesan dan pengaruh yang sangat luar biasa terhadap disiplin dan peraturan ilmu seni tarannum al-Quran.

Kitab yang dikarang oleh ramai pengarang ini menyenaraikan nama setiap qari dan meletakkan judul tertentu seperti Shaykh Muhammad Rif at sebagai Imam al-Qurra' (Ketua Qurra'), Shaykh Mustafa Isma'il sebagai al-Saut al-Zhahbi (Suara Emas), Shaykh Muhammad Sadiq alMinshawi sebagai Safir al-Sama' (Duta Langit), Shaykh Abd al-Basit sebagai Amir Dawlah al-Qurra' (Ketua Dunia Qurra'), Shaykh Abd al-Fattah al-Sha'sha'ie sebagai Abu al-Qurra' (Bapa Qurra') dan lain-lain lagi. Antara kitab-kitab lain adalah seperti berikut:

1. 'Abaqirah al-Tilawah fi al-Qarn al-Ishrin oleh Shukri al-Qadi (1997).

2. Alhan al-Sama' (edisi kedua) oleh Solahuddin Abd al-Ghani (2017).

3. Alhan al-Sama' oleh Mahmud al-Sa'dani (1996).

4. al-Mukhtar oleh Abd al-Aziz al-Bashari (1935).

5. al-Quran wa Mashahir al-Qurra' oleh Faruq Fahmi (1994). 
6. Ashar Man Qaraa al-Quran fi al-'Asr al-Hadis oleh Ahmad al-Buluk (2011).

7. Aswat min Nur oleh Mahmud al-Khawli (1992).

8. Fann Tarbiah al-Aswat oleh 'Atiyyah 'Abd al-Khaliq (1984)

9. Jamal al-Tilawah fi al-Sawt wa al-Nagham oleh al-Sayid Muhammad Rida (2012).

10. Jami' al-Nafahat al-Qudsiyyah oleh Muhammad 'Arabi al-Qabbani (1998).

11. Mawsu'ah Sufara' al-Quran al-Karim oleh Solah Salim (2012).

12. Rihlati fi al-Islam oleh Mahmud Khalil al-Husari (t.th).

13. Sawt min al-Sama' oleh Zakaria Hamimi (2009).

14. Sufara al-Quran al-Karim oleh Muhammad Abd al-Aziz Yunus (2017).

15. Sufara al-Quran oleh Ahmad Hamam (1996).

16. Usul Fann Tilawah al-Quran al-Karim oleh Muhammad Bantajah (2015).

Keseluruhannya terdapat dua puluh satu karya penulisan dalam bidang tarannum yang mengandungi tema-tema seperti biografi dan sejarah latar belakang tokoh qari, turath bacaan murattal dan mujawwad, keterlibatan qari dalam Iza'ah al-Misriyyah dan seni tilawah. Juga berkaitan sejarah perkembangan dunia tilawah di Mesir, sejarah tarannum di zaman Nabi dan para sahabat, sejarah permulaan ilmu seni tilawah di zaman kerajaan Fatimiyyah serta penglibatan qari dalam rihlah Quran. Begitu juga berkenaan tokoh-tokoh qari Hijaziyyah, kaedah teknik ilmu suara, aliran madrasah tilawah Misriyyah, dakwah al-Quran dalam masyarakat Muslim dan non-Muslim, hadithhadith tarannum, pengalaman para qari dalam bidang tilawah dan anugerah dan pengiktirafan qari. Akhirnya ia juga merangkumi cabaran qari al-Quran, taqlid (tiru) gaya bacaan, uslub (jalan) bacaan, sumber rujukan tarannum, qari al-surah di masjid dan institusi pembelajaran tarannum. Tema-tema tersebut menjadi topik penting dalam perbincangan ilmu tarannum. Impak penghasilan karya ini amat membantu dalam perbahasan bidang berkaitan kerana ia amat sukar untuk diperolehi. Implikasi penulisan ini adalah meneroka disiplin ilmu tarannum secara lebih mendalam dan dapat membezakan rujukan sumber antara seni tarannum dan bidang Quran yang lain seperti qiraat dan tajwid.

\section{References}

Abu Talib Mahmud. 2016. al-Quran bi Sawt Misr. Cairo: al-Hai'ah al-Misriyyah al-'Ammah li al-Kitab. Ahmad al-Bakri. 2014. Dawlah al-Tilawah, Aswat min al-Sama'. Cairo: Dar al-Hilal Ahmad al-Buluk. 2011. Ashhar man Qara' al-Qur'an fi al-Asr al-Hadith. Silsilah Thaqafah Shahriyyah Iqra'. Cairo: Dar al-Ma`arif.

Ahmad Hammam. 1996. Sufara' al-Qur'an. Cairo: Dar al-Yaum al-Qabbani, Muhammad 'Arabi. 1998. Jami` al-Nafahat al-Qudsiyyah. 2nd ed. Beirut: Darul Khayr. Amal al-Banna. 2011. Sawt Tuhibbu al-Mala'ikah. Cairo: Dar al-'Ulum li al-Nashr wa al-Tawzi'. 'Abd al-Aziz al-Bashari. 1935. Al-Mukhtar. Cairo: al-Matba'ah Lujnah al-Ta'lif wa al-Nashr. 'Atiyyah `Abd al-Khaliq \& Nahid Ahmad Hafiz. 1984. Fann Tarbiyyah al-Sawt wa IIm al-Tajwid. Cairo: Maktabah al-Anjalu al-Misriyyah.

Faruq Fahmi. 1994. Al-Qur'an wa Mashahir al-Qurra'. Cairo: Kitab Jumhuriyyah Misriyyah. Kamal al-Najmi. 1992. Al-Shaykh Mustafa Isma îl Hayatuh fi Zilli al-Qur'an. Cairo: Muassasah Dar alHilal.

Mahmud al-Khawli. 1992. Aswat min Nur. Cairo: Dar al-Shabab al-'Arabi.

Mahmud al-Sa'dani. 1996. Alhan al-Sama'. Cairo: Akhbar al-Yawm.

Mahmud Khalil al-Husari. n.d. Rihlati fi al-Islam. Cairo: Majma' al-Buhuth al-Islamiyyah. 
Mahmud Tawfiq al-Khawli. 2011. Qitharah al-Sama' al-Shaykh Muhammad Rifat. Cairo: al-Maktabah al-Azhariyyah.

Muhammad Abd al-Aziz Yunus. 2017. Sufara al-Quran al-Karim. Cairo: al-'Asr al-Jadid li al-Nashr wa al-Tawzi'.

Muhammad Bantajah. 2015. Usul Fann Tilawah al-Quran al-Karim. Beirut: Dar al-Kutub al-'Ilmiyyah. Nabil Hanafi. 2011. Nujum al-Asr al-Zahabi li al-Dawlah al-Tilawah. Cairo: Dar al-Akhbar al-Yawm. Sa'id Ibrahim Hasan. 2012. Aswat Samawiyyah. Desuq: Dar al-'Ilm wa al-Iman.

Shukri al-Qadi. 1997. 'Abaqirah al-Tilawah fi Qarn al-Ishrin. Cairo: Dar al-Jumhuriyyah.

Solah bin Salim. 2012. Mawsu'ah Sufara' al-Quran al-Mu'asirin. Riyadh: Maktabah al-Hadharah li alNashr wa al-Tawzi'.

Solahuddin Abd al-Ghani. 2017. Alhan al-Sama'. 2nd Ed. Cairo: Wakalah al-Sahafah al-'Arabiyyah.

Zakariya Hamimi. 2009. Sawt Min al-Sama', al-Syaikh 'Abdul Basit 'Abdul Samad. Cairo: Hibah al-Nil al-Arabiyyah.

Wan Hilmi Wan Abdullah. 2014. Pengaruh Tarannum Qari-qari Mesir Terhadap Qari-qari di Malaysia. M.A. thesis, Pengajian Islam. Bangi: Fakulti Pengajian Islam, Jabatan Pengajian al-Quran dan al-Sunnah.

Wan Hilmi Wan Abdullah \& Ahmad Asmadi Sakat \& Sabri Mohamad. 2013. Muhammad Rif at dan Turath Bacaannya. International Journal of Islamic Thought 4 : 74-81.

Wan Hilmi Wan Abdullah \& Ahmad Asmadi Sakat \& Sabri Mohamad \& Ezad Azraai. 2014. MeaningBased: Preliminary Research on Uslub Qiraah of Sheikh Muhammad Rif at (1880-1950). Middle-East Journal of Scientific Research 20(12): 2172-2176.

http://www.azhar.eg/sawtalazhar/section5/ArtMID/7501/ArticleID/15514. 2017. Retrieved: 15 November 2018.

http://ndjaawi.blogspot.my/2011/03/blog-post.html. Retrieved: 15 November 2018. 